Article

\title{
Rangeland Livelihood Strategies under Varying Climate Regimes: Model Insights from Southern Kenya
}

\author{
Rebecca Kariuki $^{1,2, *(1)}$, Simon Willcock ${ }^{3,4}$ (D) and Rob Marchant $^{1}$ (D) \\ 1 York Institute for Tropical Ecosystems, Environment Department, University of York, Heslington, \\ York YO10 5NG, UK; robert.marchant@york.ac.uk \\ 2 School of Life Sciences and Bio-Engineering, The Nelson Mandela African Institution of Science and \\ Technology, P.O. Box 447 Arusha, Tanzania \\ 3 Centre for Biological Sciences, Faculty of Natural \& Environmental Sciences, University of Southampton, \\ Highfield Campus, Southampton SO17 1BJ, UK; s.willcock@bangor.ac.uk \\ 4 School of Environment, Natural Resources and Geography, Bangor University, Deiniol Road, Bangor, \\ Gwynedd LL57 2UW, UK \\ * Correspondence: rebecca.kariuki@york.ac.uk; Tel.: +255-764-254-751
}

Received: 31 January 2018; Accepted: 10 April 2018; Published: 12 April 2018

\begin{abstract}
Rangelands throughout sub-Saharan Africa are currently undergoing two major pressures: climate change (through altered rainfall and seasonality patterns) and habitat fragmentation (brought by land use change driven by land demand for agriculture and conservation). Here we explore these dimensions, investigating the impact of land use change decisions, by pastoralists in southern Kenya rangelands, on human well-being and animal densities using an agent-based model. The constructed agent-based model uses input biomass data simulated by the Lund-Potsdam-Jena General Ecosystem Simulator (LPJ-GUESS) dynamic vegetation model and parameterized with data from literature. Scenarios of land use change under different rainfall years, land tenure types and levels of wildlife conservation support were simulated. Reflecting reality, our results show livestock grazing as the predominant land use that changes with precipitation and land tenure leading to varying livelihood strategies. For example, agriculture is the most common livelihood in wet years and conservation levels increase with increasing support of wildlife conservation initiatives. Our model demonstrates the complex and multiple interactions between pastoralists, land management and the environment. We highlight the importance of understanding the conditions driving the sustainability of semi-arid rangelands and the communities they support, and the role of external actors, such as wildlife conservation investors, in East Africa.
\end{abstract}

Keywords: agent-based-model; climate change; conservation; grazing; pastoralists; precipitation; savannahs; social-ecological systems

\section{Introduction}

Rangelands occupy $45 \%$ of the earth's land surface and $61 \%$ of the African continent [1] with $35 \%$ of African rangelands under permanent pasture [2]. They include grasslands, shrublands and savannahs used largely for livestock production and wildlife conservation that are often characterized by low productivity, sparse human population and common land use [2,3]. About $60 \%$ of global rangelands are relatively dry [1] with water scarcity common during certain months of the year $[4,5]$, leaving any local human populations who are dependent on their ecosystem services at risk that is often mitigated by migration. 
In East Africa, ecosystems are shaped by long term interactions between changing climates and human activities [6,7]. Human impact, through land use change, is one of the strongest factors changing rangelands and is driven by the demand for ecosystem services $[3,8]$. However, rainfall is a major control of human land use options [9]. Rainfall seasonality affects pasture production independent of mean annual rainfall [10]. Rainfed agriculture is only viable in areas receiving at least $700 \mathrm{~mm}_{\text {year }}{ }^{-1}$ of rainfall $[9,11]$; thus, pastoralism is the main livelihood strategy in areas of low and/or highly variable rainfall [12]. Wildlife and livestock utilize rangelands in complimentary ways [13-15] where livestock grazing maintains the rangelands for wildlife by keeping them open and as hotspots of biodiversity $[16,17]$.

In arid and semi-arid areas of Kenya, the pastoral economy accounts for $90 \%$ of all employment opportunities and 95\% of household income [18]. Pastoralists in Kenyan rangelands were organized in group ranches to allow members to own land communally, to improve livestock production and encourage socio-economic development [19]. To reduce their vulnerability to unfavorable climates and socio-economic factors, pastoralists use various adaptation and coping mechanisms such as movement of livestock, changing livestock herd composition and selling stock to get money $[18,20,21]$. In the 1970s, the Kenyan Government deemed pastoralism as an inefficient land use type [22] and encouraged sedentarization and/or land subdivision, commercialization and privatization of communal group ranches [23,24]. Furthermore, leadership in the group ranches was ineffective and did not provide equitable distribution of resources to all group ranch members leading to their dissatisfaction and prompting further subdivision $[19,25]$. As a result, by the end of the twentieth century, the future of exclusive pastoralism in East African rangelands was uncertain $[10,26]$. With increasing sedentarization and subdivision; land tenure became an important driver of pastoralists land use change decisions, agriculture expanded in wet areas and near permanent water bodies $[22,27,28]$ and wildlife conservancies were formed in response to changing climatic, socio-economic and political factors [3,17,29].

The sustainability of pastoralism is primarily threatened by climate and land use change [30] and its success depends on rainfall patterns, land availability, forage availability and socio-economic changes. About $65 \%$ of the pastoral population living in arid and semi-arid areas in Kenya live below the poverty line [31]. With low income, decreasing livestock numbers and increasing climate variability, the number of pastoralists that can rely entirely on livestock reduces making livelihood diversification and/or intensification a necessity $[1,10,11]$. Pastoralists who can no longer sustain themselves by livestock grazing use their land for agropastoralism, agriculture or real estate. These land use transformations cause rangeland fragmentation through the loss of connectivity between landscapes [23].

In contrast to some other parts of Africa, diverse wildlife species still coexist with pastoralists and agropastoralists within East Africa [1,11]. The rapidly growing human population, multiple socio-economic and political factors and the interaction between pastoralist activities and wildlife pose a challenge on how best the sustainability of East African rangelands can be addressed. This unique interaction between humans and rangeland ecosystem services make them complex social-ecological systems where adaptations between the social and ecological components need to be understood. Additionally, it is by understanding the interactions between pastoralist livelihoods and the environment that more sustainable management of pastoral lands futures in East Africa can be developed. As the interactions between components in social-ecological systems are complex, nonlinear and adaptive, perspectives from social and natural environments have been used to understand them [32]. However, integrating these perspectives is challenged by the difficulty of understanding the interactions between multiple ecosystem services and trade-offs in human impact [33] making simulation modelling a potential tool to quantitatively address the response of pastoral activities to changing socio-economic and environmental factors [34]. As such, integrated modelling could contribute to answering important questions of interest to conservation researchers and practitioners, including: Which driver (biological, climatic, or anthropogenic) is more important in driving livelihood 
strategies in rangelands? How can payment for ecosystem services enhance conservation activities in rangelands? How can trade-offs between conservation and national development be addressed to promote sustainable development? Who are the likely "winners" and "losers" in rangelands under climate change scenarios?

Our study aims to understand grazing and sedentarization levels in southern Kenyan rangelands using an agent-based model to simulate pastoral land use decision making criteria and the impact it has on animal densities and pastoral livelihoods. Two objectives were used to address this research. First, we aim to show land use change across different rainfall years and land tenure scenarios. These land use change types are simulated over varying levels of wildlife conservation support in form of maximum annual income per land use type. Second, we aim to establish the impact of land use change on livestock densities, wildlife densities and pastoralist income. These impacts are simulated over nine different scenarios of rainfall and land tenure. We hypothesize that rainfall variability and socio-economic changes influence pastoral land use change decisions as pastoralists select the land use type that remains most profitable despite changing rainfall and socio-economic patterns. We also hypothesize that the land use selected by pastoralists drives their well-being and animal densities in rangelands.

\section{Study Areas}

The Amboseli and Mara ecosystems in southern Kenya were selected for study as their ecologies, historical land use types and conservation use have broadly been similar but have changed over the recent past due to varying pastoral sedentarization levels, social-economic development, and conservation initiatives. The Amboseli ecosystem consists of the Amboseli Basin, which is mainly the Amboseli National Park, and the group ranches surrounding the park (Figure 1). The park provides a dry season grazing reserve for wildlife while the group ranches surrounding the national park provide wildlife dispersal zones. For instance, the Kimana group ranch provides a migratory corridor for wildlife migrating between the Amboseli, Chyulu Hills and Tsavo National Parks/Reserves. The group ranches were formed under the Land Act of 1968 which aimed to incorporate landowners in collective management of pastoral land and resource use [35]. The group ranches were meant to encourage pastoralists to maintain a sizeable herd and to limit livestock grazing within their group ranch boundaries [36]. However, the group ranches were ineffectively managed and the pastoralists neither reduced their herds nor restricted grazing to their ranches leading to group ranch subdivision from the mid-1980s to present $[1,36]$.

Rainfall in Amboseli is influenced by altitude [31] where higher rainfall areas occur along the northern foothills of Kilimanjaro (>800 $\mathrm{mm}_{\text {year }}{ }^{-1}$ ) and Chyulu Hills (500-600 $\mathrm{mm}_{\text {year }}{ }^{-1}$ ) [1] while lower points such as the Amboseli receive an average rainfall of $350 \mathrm{~mm}^{-1} \mathrm{ear}^{-1}[37,38]$. There are two annual rainfall seasons (November-January and March-May) and sometimes one or both of the rainfall seasons fail [1]. The ecosystem is characterized by a series of swamps, streams and rivers that are supported by the underground flows from Mt. Kilimanjaro [35,39]. Grasslands in Amboseli are dominated by Chloris rocksburghiana, Eragrostis tennuifolia and Sporobolus spp., woodlands are dominated by Commiphora and Acacia spp., swamps and flooded areas are dominated by Acacia xanthophloea, Cyperus immensus, Psilolemma jaegeri and Salvadora persica and the slopes of Kilimanjaro and Chyulu Hills are dominated by broad leaved dry tropical forests [38,40,41]. Our study was only interested in the drier parts of Amboseli and covered the Amboseli National Park and the surrounding pastoral group ranches (Figure 1).

The Mara ecosystem is north of the Serengeti ecosystem in Tanzania and provides dry season grazing reserve for wildebeests migrating from the Serengeti [42]. It consists of the Maasai Mara National Reserve and the surrounding group ranches which form wildlife dispersal zones (Figure 1). These group ranches also act as a buffer between the national reserve and the agricultural lands in the north of Narok County that are largely under mechanized agriculture $[27,40,43]$. The Mara is characterized by two rainfall seasons (November-December and March-May) with a gradient from 
the dry south eastern parts with an average rainfall of $500 \mathrm{~mm} \mathrm{year}^{-1}$, to the wet north-western parts with an average rainfall of $1200 \mathrm{~mm}_{\text {year }}^{-1}$ [40,44]. The average temperature is $18{ }^{\circ} \mathrm{C}$ [45]. There are several permanent and seasonal rivers and streams in the Mara and they all flow into the Mara River [46]. Vegetation in the Mara is characterized by open woodlands and forests along river and water courses [46]. Our study area in Mara covered the Maasai Mara National Reserve and the surrounding group ranches (Figure 1).

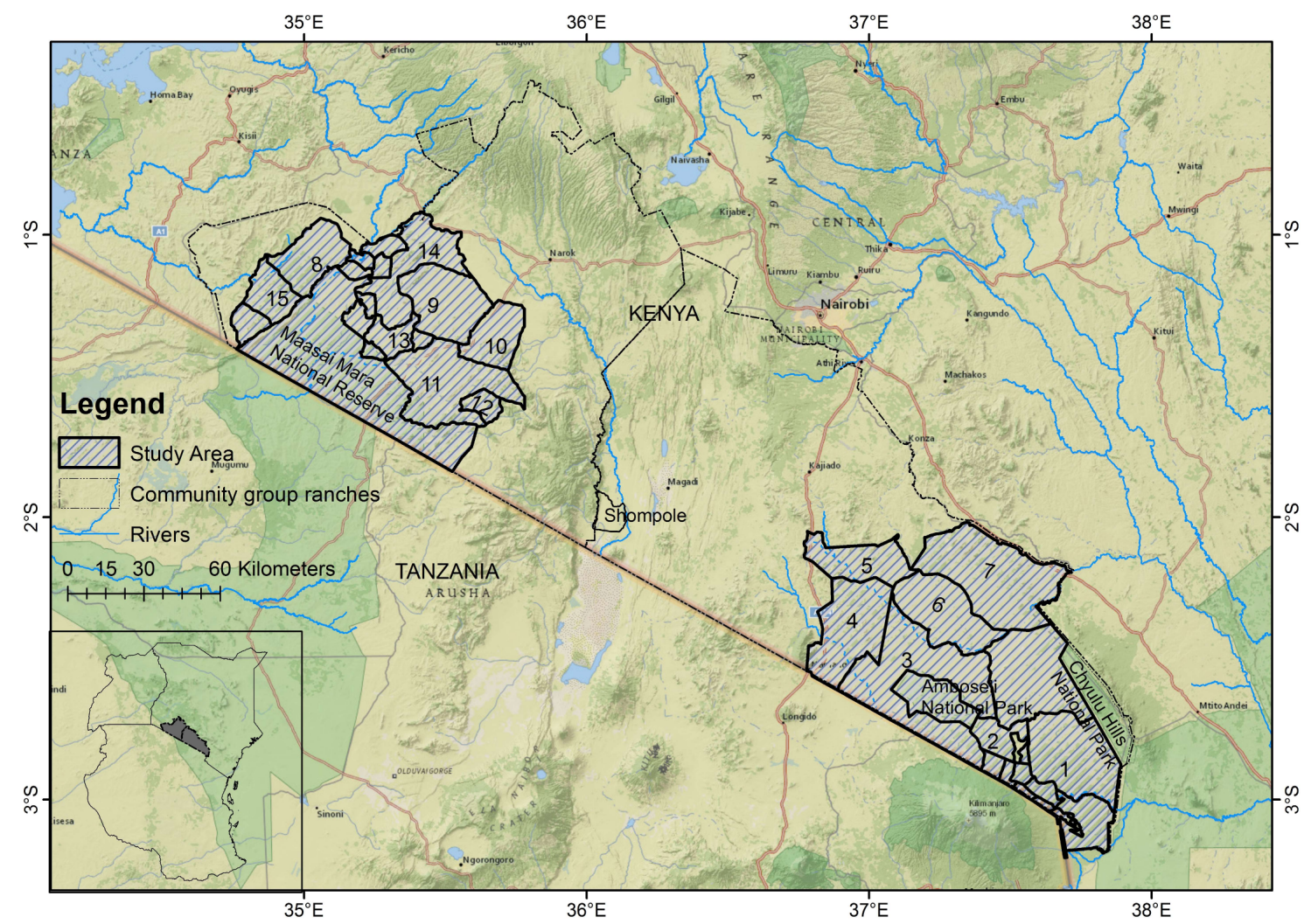

Figure 1. Amboseli and Mara ecosystems in southern Kenya and the surrounding group ranches (numbered 1-15). Group ranches 1 to 7 are in Amboseli while group ranches 8 to 15 are in the Mara. The name for the numbered group ranches are as follows: 1-Kuku, 2-Kimana, 3-Olgulului/Ololorashi, 4-Mailua, 5-Osilalei, 6-Lengesim, 7-Kaputei South, 8-Kimintet, 9-Ol Kinyei, 10-Maji Moto, 11-Siana, 12-Naikara, 13-Naboisho, 14-Lemek and 15-Oloirien. Those areas specifically modelled in this investigation are shaded. Group ranches in Amboseli were digitised by the International Livestock Research Institute (ILRI) while those in Mara were digitised by Benson Maina. Base layer Source: National Geographic.

\section{Methods}

Agent-based models (ABMs) are used to study complex adaptive systems made up of interactive, autonomous agents which give the system an ability to adapt, self-organize and show emerging patterns [47-50]. They simulate the behavior of agents from bottom-up to show the influence of individual agents in explaining the emergent patterns of a system [51-54]. ABMs can be used to link biophysical and socio-economic components of a system by incorporating outputs from biophysical process-based models as input data and linking them to other socio-economic factors simulated in the model $[34,51,55]$.

The Lund-Potsdam-Jena General Ecosystem Simulator (LPJ-GUESS) dynamic global vegetation model $[56,57]$ is a deterministic, process-based dynamic global vegetation model that simulates changes in vegetation dynamics and biogeochemical cycles as a function of changing climates [58-62]. 
LPJ-GUESS uses gridded time series climate data, atmospheric carbon dioxide $\left(\mathrm{CO}_{2}\right)$ concentrations and soil physical properties as input data [62]. Vegetation is described as plant functional types (PFT) distinguished by bioclimatic limits, morphological, phenological, life history traits and photosynthetic pathway [60]. Simulated vegetation dynamics arise from competition for light, space, and soil resources among plant functional types [57,63]. Validation of LPJ-GUESS has been done by measures of vegetation structure, composition and productivity [61], and with vegetation maps, remote sensed and pollen data $[64,65]$.

We apply an ABM to a social-ecological system [66] in Amboseli and Mara ecosystems in southern Kenya to understand the feedback between pastoral land use activities and natural resources. We link our custom-build ABM (details below) to LPJ-GUESS dynamic global vegetation model.

\subsection{Our Model Description and Dataset}

We developed a novel ABM in NetLogo (version 6.0.2) [67]. To the best of our knowledge, this is the first model that integrates a process-based dynamic global vegetation model and an ABM to assess the interaction between climates, livelihoods, and conservation in East African rangelands. The description of the model follows the ODD (Overview, Design concepts and Details) protocol (Appendix A) [68,69] formulated to make models complete, reproducible and easy to communicate [70]. The period for the ABM is from 1950 to present. To parameterize ecological and socio-economic variables used in the ABM, we used data on animal densities, grazing rates, income levels, household densities and irrigation probabilities from literature focused on pastoralists/agropastoralists in the study areas [39,71-73] and from the 2009 Kenya census [74] (Table 1).

Table 1. Model variables, their descriptions and data sources. Variables are divided into two types: fixed variables are constant throughout the model run, while updated variables are continually altered throughout the model based on other parameters.

\begin{tabular}{|c|c|c|c|}
\hline State Variables & Description/Units & $\begin{array}{l}\text { Variable } \\
\text { Type }\end{array}$ & Data Source \\
\hline Land tenure-type of land ownership & $\begin{array}{l}\text { Communal, government and } \\
\text { private }\end{array}$ & fixed & $\begin{array}{l}\text { Randomised (see } \\
\text { Appendix A) }\end{array}$ \\
\hline Land use-current land use in the land area & $\begin{array}{c}\text { Livestock grazing, irrigated } \\
\text { agropastoralism, agriculture, } \\
\text { livestock grazing with conservation } \\
\text { activities and built-up }\end{array}$ & updated & $\begin{array}{l}\text { Assigned via the } \\
\text { NetLogo model }\end{array}$ \\
\hline $\begin{array}{c}\text { Households-the density of homes found } \\
\text { in the land area }\end{array}$ & $\begin{array}{l}\text { Number per kilometre squared } \\
\qquad\left(\# / \mathrm{km}^{2}\right)\end{array}$ & fixed & [74] \\
\hline $\begin{array}{l}\text { Distance to the road-the closeness of a } \\
\text { grazing land to the nearest all-weather road }\end{array}$ & $\mathrm{km}$ & fixed & [73] \\
\hline $\begin{array}{l}\text { Irrigation-probability-the likelihood that a } \\
\text { pastoralist will irrigate his/her land based } \\
\text { on the overall likelihood of irrigation in the } \\
\text { study areas }\end{array}$ & Probability of $0-1$ & fixed & [75] \\
\hline $\begin{array}{l}\text { The annual income earned from specific } \\
\text { land uses practiced in } 1 \mathrm{~km}^{2} \text { land area }\end{array}$ & Dollars per year $\left(\$\right.$ year $^{-1}$ ) & updated & [40] \\
\hline $\begin{array}{l}\text { Income-the highest income from different } \\
\text { land uses practiced in } 1 \mathrm{~km}^{2} \text { land area }\end{array}$ & $\$$ year $^{-1}$ & updated & $\begin{array}{l}\text { Calculated by the } \\
\text { NetLogo model }\end{array}$ \\
\hline $\begin{array}{l}\text { Grass biomass-the amount of grass } \\
\text { available for livestock and wildlife grazing } \\
\text { in } 1 \mathrm{~km}^{2} \text { of land area }\end{array}$ & $\begin{array}{l}\text { Kilograms per kilometre squared } \\
\qquad\left(\mathrm{kg} / \mathrm{km}^{2}\right)\end{array}$ & Updated & LPJ-GUESS [56,57] \\
\hline $\begin{array}{l}\text { Livestock density-the number of tropical } \\
\text { livestock units (TLU) in } 1 \mathrm{~km}^{2} \text { of land area }\end{array}$ & TLU & Updated & [40] \\
\hline $\begin{array}{l}\text { Wildlife density-the number of wildlife } \\
\text { found in } 1 \mathrm{~km}^{2} \text { of land area }\end{array}$ & $\# / \mathrm{km}^{2}$ & Updated & [39] \\
\hline
\end{tabular}


To represent the density of livestock in the ABM, we used tropical livestock units (TLU). TLU are a composite index used to standardize livestock species according to their body weight whereby one TLU is equivalent to $250 \mathrm{~kg}$ which is the weight of a female zebu cow $[13,40,76,77]$. TLU as a measure allows comparison of livestock species and wealth across pastoral households [78] whereby a cow is approximately 1 TLU and one goat or sheep is 0.125 TLU [13]. Other ABM studies that use TLU to understand the behavior of pastoral systems in Africa include [34] who simulates the decision making system of household heads with regard to ecosystem services and [49] who studied the role of herd numbers and stochastic events on the growth of herds. For each parameter we used the mean and standard deviation to incorporate stochasticity in the ABM. To capture multiple land use change behaviors observed in the ABM, we applied the principle of pattern oriented modelling [79] in the model design. We used insights from semi-structured interviews conducted with pastoralists in the study areas in January and February 2016. The interviews focused on questions on the history and drivers of land use patterns, land tenure, livelihood strategies and land management. In the model, the important role of government policy in advocating for land subdivision in the study areas is reflected through the land tenure variable that has three land tenure scenarios (communal, government and private).

Long term mean rainfall and temperature estimates from Climatic Research Unit TS 3.0 dataset, Climate Research Unit (CRU) University of East Anglia [80] were used in LPJ-GUESS to simulate vegetation biomass for the Amboseli and Mara ecosystems for the period between 1950 and 2005. As LPJ-GUESS simulations are run at both daily and annual time steps over a spatial resolution of 0.5 degrees [81], we simulated grass biomass annually and converted the output to $\mathrm{kg} / \mathrm{km}^{2}$. Grass biomass from three representative years in Amboseli (1990, 1993 and 2001) and Mara (1983, 1987 and 1994) were used to represent dry (low biomass), normal (medium biomass) and wet (high biomass) years respectively. Grass biomass was then used as input data for the ABM and used to simulate grass biomass that was available to wildlife and livestock based on their feeding rates and the land use practiced on a given cell. The model assumed an animal of $250 \mathrm{~kg}$ (equivalent of one tropical livestock unit) grazes on $2500 \mathrm{~kg}$ of dry matter per year [72]. It also assumed that all cells used for livestock grazing land use were grazed by livestock alone, half of the cells used for irrigated agropastoralism land use were grazed by livestock, one-third of the cells used for livestock grazing with conservation land use were grazed by livestock while two-thirds were used by wildlife and all the cells used for agriculture and urban land use types had no livestock or wildlife grazing.

From the grass available for grazing, wildlife and livestock densities were simulated for each cell. Animal densities, together with the likelihood of irrigation, type of land tenure, distance to road, household density and the price of livestock were then used to simulate the potential income a pastoralist can earn from different land uses in a given cell. From each cell, the land use type that had the highest income was then selected as the preferred land use type. In addition, the wildlife and livestock density in that cell were simulated as model outputs.

As our model was interested in understanding land use change types and their impacts on animal density and pastoralists' income, it was not spatially explicit. However, the patterns underlying the designing and implementation of our model are based on patterns observed and documented for Amboseli and Mara.

\subsection{Simulation Experiments}

\section{Scenarios}

We used repeated scenario experiments to explore a range of possible behaviours of the system from changing interactions between model variables. In the model, the variables used for computing different scenarios are the types of rainfall years (dry, normal and wet), and land tenure (communal, government and private), combined with modification on the amount of money available to support pastoralists who are willing to rent their land to be used for wildlife conservation (ranging $0-1000 \$$ year $^{-1}$ ) 
(See Appendix A for full details). Simulation of each scenario was done independently from the start to the end and there was no alteration between scenarios when running the model.

\section{Results}

Our main findings were: (1) with no conservation subsidies, livestock grazing remains the main land use type on dry, normal and wet years across all land tenure scenarios; (2) agriculture levels increase on subdivided and privatised land on all rainfall years; (3) provision of conservation subsidies heightens livestock grazing with conservation land use and; (4) livestock numbers, wildlife numbers and pastoralist income go up with higher conservation subsidies and decline with low conservation subsidies. Broadly, our findings were consistent across both Amboseli and Mara, and so we focus on Amboseli here, highlighting any differences with Mara throughout. For further details on the results for Mara please see the supplementary information.

\subsection{Land Use Change in Normal Rainfall Year}

Our model assumed the normal rainfall year formed the baseline conditions in the rangeland. The levels of irrigated agropastoralism land use under all the different scenarios was negligible while livestock grazing with conservation was not practiced when there were no conservation subsidies.

In a normal rainfall year, the three land tenure scenarios are dominated by livestock grazing when there is no budget to support conservation initiatives. When the conservation budget increases, livestock grazing with conservation becomes the predominant land use type followed by agriculture, livestock grazing and built-up land uses (Figure 2). Compared to communal and government land tenure scenarios, the private land tenure scenario had higher levels of agriculture.
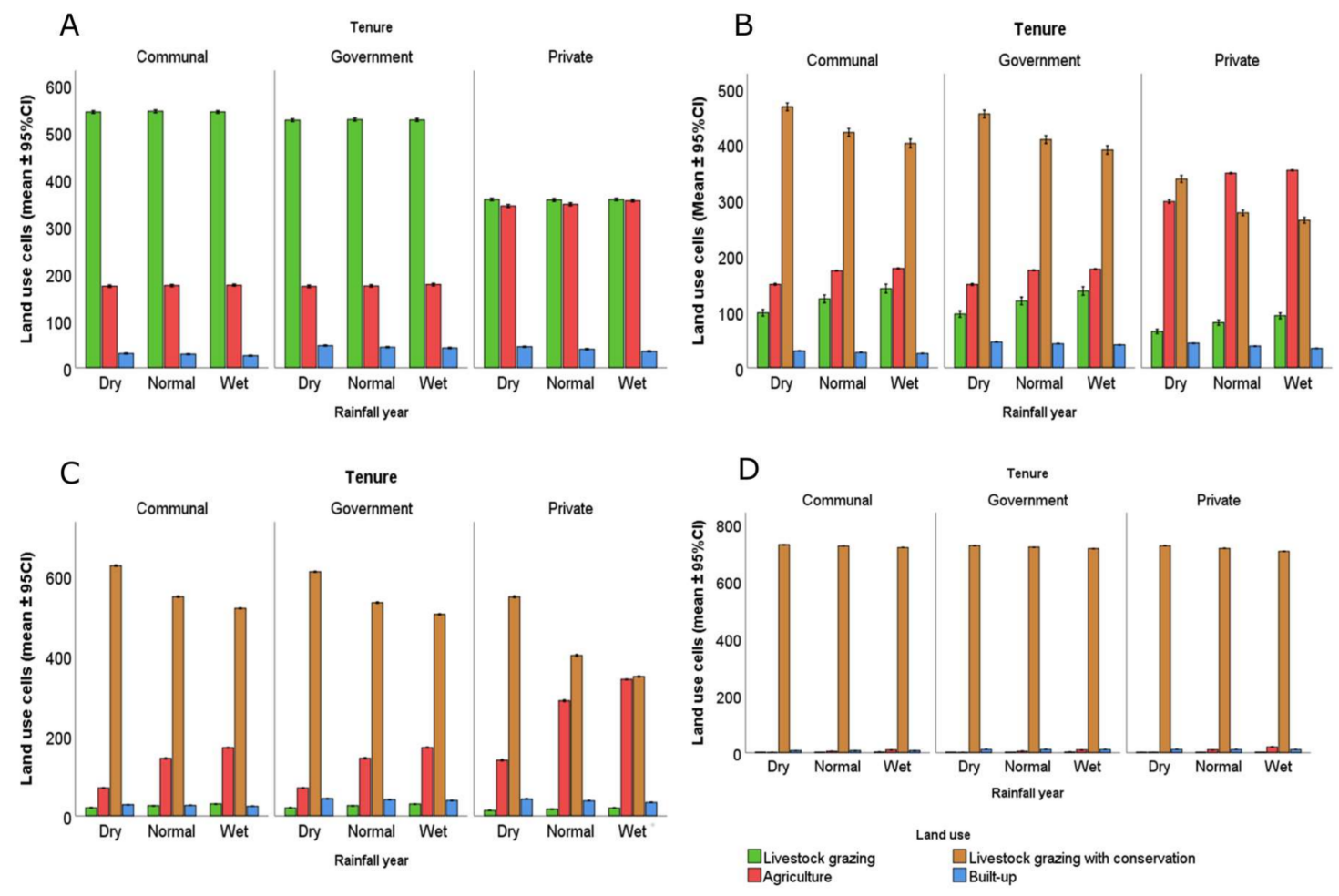

Figure 2. Comparison of land use types at different levels of conservation subsidies in Amboseli. In (A) there is no conservation subsidy, in (B) the conservation subsidy ranges from 10 to $100 \$$ year $^{-1}$ while in (C,D), the conservation subsidy ranges from 110 to $200 \$$ year $^{-1}$ and 210 to $1000 \$$ year $^{-1}$. In all the graphs, the three land tenure scenarios are labelled as 'Tenure'. The error bars represent $95 \%$ confidence interval. 


\subsection{Land Use Change in Dry and Wet Rainfall Years}

Land use trends during the dry rainfall year are mainly similar to the normal rainfall year apart from the private land tenure scenario where increase in agriculture levels is higher (Figure 2). One key difference between Amboseli and Mara in a dry rainfall year is that in Mara, under the private land tenure scenario, livestock grazing decreases as agriculture increases while in Amboseli livestock grazing does not decline as agriculture increases.

In a wet rainfall year, livestock grazing is the main land use type in communal and government land tenure scenarios. However, under the private land tenure scenario, both livestock grazing and agriculture levels are high.

\subsection{Land Use Change over Different Conservation Budgets}

In a normal rainfall year, as the conservation budget increases, livestock grazing with conservation dominates and all other land uses decline leading a wide margin between the levels of livestock grazing with conservation land use and other land use types. Under the private land tenure scenario, between 10 and $90 \$$ year $^{-1}$ of conservation budget, agriculture is the main land use type after which livestock grazing with conservation dominates as the conservation budget increases.

In a dry rainfall year, under communal and government land tenure scenarios, livestock grazing is the predominant land use type at conservation budget of $10 \$$ year $^{-1}$. However, when the budget increases to $20 \$$ year $^{-1}$, livestock grazing with conservation becomes the main land use type followed by agriculture, livestock grazing and built-up in that order with the built-up areas surpassing livestock grazing as the conservation budget continues to rise. Similar trends are observed in the Mara. However, unlike Amboseli, overall trends in the Mara show agriculture levels declining faster as conservation budget increases. During a wet year, under the communal land tenure scenario, a provision of 10-20 $\$$ year $^{-1}$ of conservation budget raises the level of livestock grazing with conservation. Similar trends are observed under the government land tenure scenarios. However, land use trends differ between Amboseli and Mara under the private land tenure scenario. In Amboseli, below a conservation budget of $150 \$$ year $^{-1}$, the private land tenure scenario has high levels of agriculture and livestock grazing with conservation and low levels of the built-up and livestock grazing land use. At $160 \$$ year $^{-1}$, livestock grazing with conservation and agriculture are practiced in somewhat equal levels after which agriculture decreases as the conservation budget increases. In Mara, when a small budget $\left(<20 \$\right.$ year $\left.^{-1}\right)$ is available for conservation, agriculture increases as livestock grazing diminishes and at $30 \$$ year ${ }^{-1}$ of conservation budget, livestock grazing with conservation land use overtakes agriculture and increases proportionally with increasing conservation budget.

Under all three land tenure scenarios, in a wet rainfall year, the level of livestock grazing with conservation in Mara is higher than in Amboseli while the levels of agriculture and built-up land are higher in Amboseli than in the Mara.

\subsection{Impact of Land Use Change on Wildlife, Livestock and Pastoralist Income}

Overall, wildlife density was higher in a wet rainfall year compared to normal and dry rainfall years (Table S1). It was also higher under communal and government land tenure scenarios than under the private land tenure scenario. In all rainfall and land tenure scenarios, as the conservation budget goes up, livestock grazing with conservation land use predominates leading to higher wildlife density (Figure 3 and Figure S2). The highest wildlife density was recorded in a wet rainfall year under the communal land tenure scenario while the lowest wildlife density was recorded in a dry rainfall year under the private land tenure scenario (Table S1). 

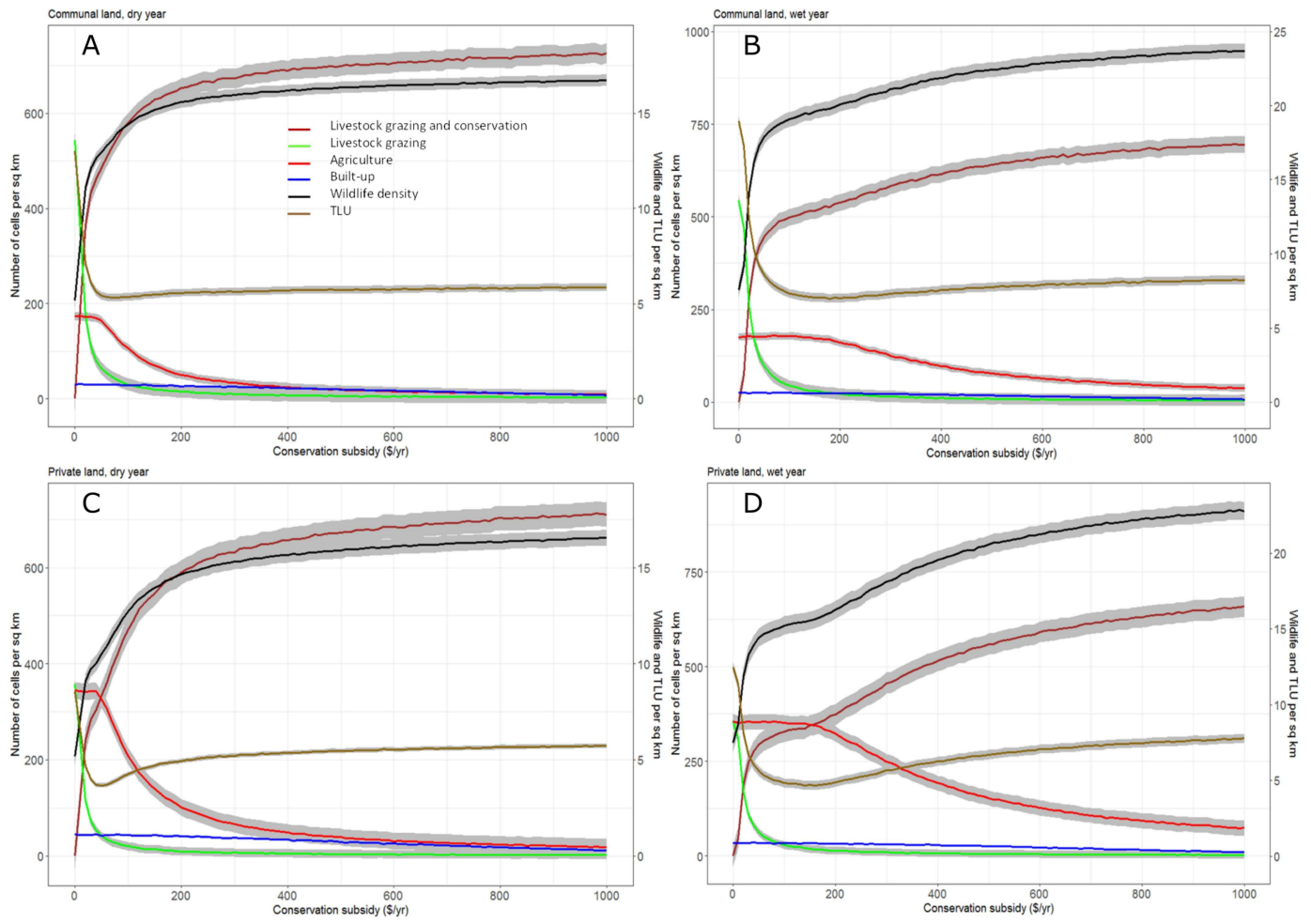

Figure 3. Trends in the relationship between land use types, wildlife and livestock density (TLU) in Amboseli. Figure $(\mathbf{A}, \mathbf{B})$ show dry and wet year trends under the communal land tenure scenario while figures (C,D) show dry and wet year trends under the private land tenure scenario. In all the figures, the grey zones represent the $95 \%$ confidence interval. From the figures, animal density increases with conservation subsidies though at different levels under different rainfall years and land tenure scenarios.

For all rainfall and land tenure scenarios, when there is no support for conservation, livestock grazing is the main land use type leading to higher livestock density relative to wildlife (Figure 3 and Figure S2). Livestock density follows similar trends to wildlife where livestock density is higher in the wet rainfall year compared to the normal and dry years and private land tenure scenarios have less livestock density when compared to communal and government land tenure scenarios.

Income earned by pastoralists from different land use types was higher during the wet year and under private land tenure scenario. Income increased as the conservation budget increased since land use types such as agriculture and livestock grazing with conservation earned pastoralists more income than livestock grazing or urbanization.

\section{Discussion}

By combining LPJ-GUESS with the land use change ABM, we aimed to integrate the impact of natural and social factors in pastoral land use decisions. Other studies in southern Kenyan rangelands that have integrated ABMs and biophysical models have been used to study: (1) the well-being of pastoralists in response to drought by simulating scenarios of lack of access to grazing resources and compensation for loss of grazing resource [34]; (2) to explore the possibility of payment for ecosystem services to pastoralists whose land use types are compatible with wildlife conservation [82] and; (3) to quantify the impact of land subdivision to livestock numbers and food security of households in Kajiado [83]. Our modelling work has shown the feedbacks between pastoral land use change decisions, their well-being and animal densities. With trends in land use, droughts and rainfall seasonality in East 
Africa expected to change in the future these land use change insights will improve our understanding of potential impacts of land use change on ecosystem services in East African rangelands.

The relative importance of livestock grazing, as the dominant land use type across southern Kenyan rangelands, change as rainfall, land tenure and conservation benefits change. Although land use changes have been attributed to multiple interactions between bio-physical and socio-economic factors, these interactions are complex, non-linear and difficult to include in land use analysis [84]. Livestock grazing is the most viable land use type in arid and semi-arid savannahs as it allows seasonal movement of livestock between dry and wet season grazing reserves $[39,85,86]$. It is also compatible to wildlife conservation [17], promotes cultural diversity [86] and supports many livelihoods thus making a significant contribution to the gross domestic product (GDP) of many East African countries [87]. However, climatic variability, manifested as delayed/failed rains, unreliable intensity of rainfall and increased frequency of droughts, drives rangeland conditions and impact on fodder available for livestock [88-90]. There is an increase in livestock grazing and agriculture during wet years in both Amboseli and Mara (Appendix B). This is because when adequate forage and water is available for livestock during wet years, pastoralists tend to maintain their livelihoods. Pastoralists also tend to practice agriculture where irrigated or rain-fed agriculture can be supported [88] leading to agricultural expansion in wet years and contraction in droughts or when there is intensified competition with wildlife [40].

Trends in the levels of irrigated agropastoralism, conservation and built-up land use are not different across the three rainfall years. This is probably because our model only considers three representative (dry, normal, and wet) rainfall years and not rarer extreme events. Also, despite rainfall being a key determinant of the main land use types in rangelands [35], and pastoralists using different adaptive strategies to droughts, it is extreme droughts that lead to rapid pastoral land use change and sedentarization [1]. This means that even the best land management techniques used to mitigate the effects of drought can fail under extreme droughts [91].

The influence of land fragmentation is modelled through land tenure scenarios in which the communal and government land tenures scenarios are largely un-subdivided and are used jointly by community members. On the other hand, the private land tenure scenario is largely divided into individual titled parcels of land and land use decisions are individual-based. Our model results show that the levels of livestock grazing land use were high under communal and government land tenure scenarios compared to private land tenure scenarios. In contrast, agriculture levels were higher under private land tenure scenarios compared to the other land tenures. These trends are synonymous to the increasing smallholder agriculture and sedentarization levels that have occurred in pastoral areas in southern Kenya following land subdivision $[38,43,92,93]$. Agriculture compartmentalizes rangelands components by introducing fences and water canals and utilizing dry season grazing lands as farms [88]. Changes in land tenure are driven by internal and external factors and lead to different land use change choices. Pastoralists, sometimes, encourage land subdivision when they are interested in controlling their land by keeping off agriculturalists and conservationists from gaining access to their lands [88]. Other times, when there is uncertainty over the leadership and effectiveness of communal land tenure, land privatization is encouraged, and pastoralists decide how to use their land. The outcome of land privatization is a decline in exclusive pastoralism, increased sedentarization and livelihood diversification [22].

Though our results show livestock grazing and agriculture levels increasing in the wet years, agricultural expansion during wet years under private land tenure scenarios is higher than the expansion of livestock grazing. As opposed to mechanized agriculture which is driven by land suitability and economic factors such as market accessibility; smallholder agriculture is driven by changes in demographic and socio-economic factors [27]. The goal of government policies that supported the privatization of communal lands was to promote intensive livestock production [25,31,94]. However, privatization promoted land fragmentation that discouraged pastoral mobility $[1,25,94]$ and encouraged agriculture and settlements expansion, land privatization and sedentarization $[1,42,95]$. 
Besides rainfall and land tenure, the impact of external drivers such as conservation investors and politics are equally important in shaping pastoral land use change decisions [96]. Our results show the potential impact of conservation subsidies. In our model, conservation land use is not practiced when there is no conservation budget but increases with the conservation support provided. This is because pastoralists view conservation as a livelihood that complements pastoralism, rather than as a main livelihood [17]. When they receive wildlife related economic benefits, their perception towards conservation is positive consequently leading to an increase in wildlife numbers $[24,97]$. Wildlife and livestock densities from the model are also correlated with conservation support. National parks and game reserves in Kenya cover $8 \%$ of the land surface and account for $35 \%$ of wildlife $[14,98]$. However, between $65 \%$ and $70 \%$ of wildlife is found in communal lands surrounding protected areas [14,99]. Thus, it is important that income from conservation is extended to pastoralists nearby protected areas to encourage a more permeable matrix outside of protected areas [82]. Such conservation-orientated income could provide an important safety-net for pastoralists, especially during dry years $[3,17,76]$. To help manage this matrix, fragmented rangelands across Kenya are being merged and managed together in form of wildlife conservancies $[3,100]$. Conservancies are lands set aside for wildlife and tourism with controlled livestock grazing to promote wildlife conservation and pastoral well-being through partnerships between tourism operators and landowners $[17,29,40,101]$. The tourism operators manage the conservancy and pay landowners fixed land lease payments (maximum of 50 dollars per hectare per year) to voluntary vacate their land and refrain from putting up settlements, overgrazing and practicing agriculture $[17,102]$. As the conservancies discourage agriculture, due to its unsustainability and the human wildlife conflicts it brings [22,103], they encourage controlled livestock grazing which is seen to be compatible to wildlife conservation [82,103] leading to higher livestock grazing levels and no agriculture in conservancies. These community-based wildlife conservancies have been documented as successful in enhancing wildlife populations compared to other non-community-based wildlife zones [24]. For instance, formation of Nakuru Wildlife Conservancy, in central Kenya, is attributed to increasing the numbers of 32 wildlife species [99].

Our model results also highlight the impact of climate on wildlife and livestock, both of which show an increase in their densities during a wet year. Herbivore biomass has been associated with rainfall and food availability implying that it goes up in wet seasons and declines during droughts [99]. Simulation of wildlife and livestock densities across different land tenure scenarios showed both their densities were higher on communal and government land tenure scenarios compared to private land tenure scenario. This is because land subdivision and sedentarization disrupts the distribution and mobility of wildlife and livestock and may lead to their decline $[15,24,104]$. Over the late twentieth century and early twenty first century, wildlife densities in East African savannahs have declined [15]. Initial wildlife declines were recorded on wet pastoral areas where agriculture had expanded while drier pastoral areas where land was communally owned and not subdivided recorded relatively high wildlife density [24]. Similar wildlife trends have also been observed in southern Kenya where subdivided group ranches have lower wildlife densities compared to ecologically similar un-subdivided group ranches [24,104].

With increasing pastoral sedentarization, livestock density has also been declining in East African rangelands. To a great extent the wealth of Maasai pastoralists is associated with livestock and the number of TLU per person is used for estimating the wealth of households [78]. Per capita number of TLU needed by a pastoral family for subsistence and survival during droughts is six [77]. With per capita livestock numbers in East African rangelands having reduced from 10 in the 1960s to four in the 1980s [10], the ability of pastoral communities to depend entirely on livestock grazing for their subsistence is declining leading to diversification and intensification of pastoral livelihood strategies on and off the land [40,92]. However, our model shows that provision of conservation subsidies increases livestock density, particularly under the private land tenure scenario. It also shows that the influence of conservation subsidies in driving livestock density is key when subsidies are $<200 \$$ year $^{-1}$ and 
further increases in the subsidies maintains wildlife and livestock density levels. This means that average conservation subsidies of $200 \$$ year ${ }^{-1}$ for $1 \mathrm{~km}^{2}$ grazing land can allow pastoralists to practice livestock grazing, thus maintaining their cultural heritage, and promote wildlife conservation.

Though our model simulations provide useful trends on land use change, pastoral well-being, and animal densities, it has some limitations. Firstly, it was not spatially explicit and the location of pastoralists land, though randomly assigned, could not be linked to environmental and socio-economic conditions. A spatially explicit ABM would have enabled the agents to make decisions based on the prevailing environmental and socio-economic conditions [34]. Secondly, to reduce the complexity of interpreting the model output, our model did not use time series data of changing rainfall and biomass amounts. Instead, we used three representative rainfall years and biomass available for animals was related to these years. Utilizing time-series data would provide detailed information that is useful for predicting the behavior of the system $[105,106]$. Thirdly, our model is sensitive to conservation subsidies because pastoral land use change decisions are primarily driven by income. Thus, as the subsidies increase, more pastoralists change to livestock grazing with conservation land use because it gives them higher income. However, our model shows that pastoralists will rely on conservation income only when conservation subsidies supplement their livestock grazing income. Similar trends have been documented in southern Kenyan rangelands where conservancy payment is ranked second or third income earner and is an important source of cash that prevents pastoralists from selling their herds when they need cash [17]. With rainfall variability in Africa expected to increase [89,107], how pastoralists respond to harsh weather patterns and ecosystem changes will challenge the resilience of rangelands and their ability to adapt to fast, slow, broad scale or fine scaled drivers of change [11]. Previous studies $[17,88,108]$ have demonstrated the resilience and adaptive capacity of pastoral social-ecological systems in East Africa, and insights from modelling studies complement and inform the potential behavior of pastoral systems under changing climates, development and political factors. These insights not only help in understanding the sustainable management of other rangelands across East Africa but can be used to inform appropriate policy and practice. Based on our model results, we recommend the use of stakeholders' perceptions in informing land use change modelling studies. The results from modelling studies can then be shared with the stakeholders who should also be involved in developing future scenarios of sustainable land use policy and practices. Furthermore, we recommend the development of policies that support and manage the provision of conservation subsides in rangelands as this provides adaptation strategies to climate change as well as prevents land fragmentation and consequently, land use change in rangelands.

\section{Conclusions}

In this study, we combine a process-based model to an agent-based model to understand the impact of interacting biophysical and socio-economic factors in driving land use patterns across two rangelands in southern Kenya. By using grass biomass estimates, simulated by LPJ-GUESS dynamic global vegetation model, as input to the agent-based model, we show how biophysical and agent-based models can be integrated. From the model outputs we discuss the implication of land use change on pastoral well-being, by simulating changes in pastoralist income and livestock density, and on rangeland ecology, by simulating changing trends in wildlife density. We show the role of conservation subsidies, in form of annual income, in enhancing livestock grazing and conservation land use type across the rangelands. Our model shows that this land use type not only increases pastoralists' income, livestock, and wildlife density, but also promotes rangeland connectivity across fragmented rangelands as it emerged the main land use type when conservation subsidies are provided under the private land tenure scenario. By simulating land use trends across two study areas, our model was able to simulate similarities and differences in land use trends across two ecological similar rangelands. It also showed changing landscapes and livelihoods patterns in Kenyan rangelands and the factors that drive these changes. These insights are useful in highlighting the impact of multiple, interacting climatic, socio-economic, and political factors in shaping livelihood strategies and ecological responses 
across semi-arid rangelands in East Africa. They can also be used to better understand the changes and the challenges faced by these social-ecological systems. Thus, providing ways of developing practical solutions that will enhance environmental sustainability and human well-being, particularly in addressing questions on the longevity of pastoralism and the trade-offs between land use types.

Supplementary Materials: The following are available online at http:/ www.mdpi.com/2073-445X/7/2/47/s1.

Acknowledgments: We are grateful to the local community experts we interviewed and whose views informed the designing of the agent based model. We thank Rebecca Muthoni, Francis Sopia, Daniel Letee and John Lembakuli for their help in conducting the interviews. We appreciate the support in model development granted by the SES-LINK project at the Stockholm Resilience Centre (SRC), Sweden. The research permit for this study was issued by the National Commission for Science, Technology and Innovation (NACOSTI) in Kenya. This research was supported by the European Commission Marie Curie Initial Training Network grant to RM for the Resilience in East African Landscapes (REAL) (FP7-PEOPLE-2013-ITN 606879) project. Finally, we would like to thank the anonymous reviewers, whose comments improved the manuscript.

Author Contributions: Rebecca Kariuki and Simon Willcock developed the model. Rebecca Kariuki led the writing of the manuscript with substantial feedback from Simon Willcock and Rob Marchant. All authors contributed to the development of ideas and drafts and gave their final approval for publication.

Conflicts of Interest: The authors declare they have no conflict of interest.

\section{Appendix A. ODD Protocol}

The ODD protocol used to simulate the model is described below.

\section{Appendix A.1. Overview}

\section{Appendix A.1.1. Purpose}

The ABM seeks to understand the feedback between pastoral land use change and the ecology of southern Kenya by exploring the role of rainfall, socio-economic and governance factors in driving land use types and the impact of adopted land use types on livestock densities, wildlife densities and pastoralists' annual income. Land use change by pastoralists means changes from livestock grazing to other land use types such as agricultural expansion and urbanization because of shifting livelihood strategies.

This model is developed for researchers and decision makers to improve understanding of the influence of climate change, government policy and socio-economic development on pastoral land use decisions and the impact of land use change on pastoral well-being and wildlife.

\section{Appendix A.1.2. Entities, State Variables and Scales}

The model has one agent; "cells", which represents areas of land that can be used. The state variables for cells are listed in Table 1. Climatic variability, social-economic and political factors are the main reasons pastoralists in semi-arid rangelands change to other land use types $[1,10,22,38,85,92,96,109]$.

From our field observations and literature, the main land use changes and livelihood diversification in the study areas are expansion of agriculture, urbanization and ecotourism [40,93]. Consequently, our model distinguished five land use types and for each $1 \mathrm{~km}^{2}$ "cell" more than one land use could be practiced. Our model only simulates small-holder agriculture that is dependent on rainfall and is practiced in wildlife dispersal communal grazing lands. We do not simulate mechanized agriculture as it was rare in our study areas.

The environment is composed of amount of rainfall per year (low, normal, and high) and budget available to pastoralists from investors and non-governmental conservation organizations to support wildlife conservation. The temporal setting for the model simulations is based on biophysical and socio-economic conditions from the 1950s and is simulated on an annual time step over 200 model runs. The spatial resolution for a single cell is $1 \mathrm{~km}^{2}$ and a single cell can have multiple households, land tenure and land ownership types. 
Appendix A.1.3. Process Overview and Scheduling

The processes in the model are simulated in five steps related to natural and social-economic events that influence land use change decisions by pastoralists. Changes in rainfall influence the grass biomass available for livestock and wildlife to graze on. The density of livestock and wildlife, together with other socio-economic factors, drives the income pastoralists can earn from different land use types. In turn, the land use types that pastoralists choose have implications on their income and the density of livestock and wildlife.

The five processes and the order they are modelled in are listed below. The state variables are updated in each process.

i. Grass is assigned to every cell. The grass biomass depends on the rainfall year. A wet year produces more grass and a dry year produces less grass.

ii. Animal grazing: The current land use type and grass biomass on each cell is checked and used to simulate the livestock and wildlife density that can graze that given cell.

iii. Income calculation: For each cell, the income earned for each land use type was calculated. This depends on: the number of households on that cell, the rainfall year, available grass biomass for animals, probability of irrigation, land tenure, household density and distance to the road.

iv. Land use change: In each cell, the land use type with the highest income is selected as the preferred land use type by pastoralists.

v. In each cell, the number of selected land use type, the income, the mean wildlife and livestock density is calculated and updated for every time step.

Appendix A.2. Design Concepts

Appendix A.2.1. Basic Concepts

The basic principles principles underlying the model design are based on real world patterns observed in the study area. Land use change choices by pastoralists are based on what is most rewarding financially at each time step. The potential income for each land use type in each cell is calculated and the land use that gives the highest income is selected.

\section{Appendix A.2.2. Emergence}

Feedback between social-economic and biophysical variables emerge from the interactions between grass biomass, animal density and land use types. Land use change to agriculture mainly occurs in wet rainfall years among pastoralists with private land ownership. Change to irrigated agropastoralism largely occurs near permanent water bodies while livestock grazing with conservation activities is preferred in areas where pastoralists derive monetary benefits, mainly through land rents, from investors or organizations supporting wildlife conservation initiatives.

Appendix A.2.3. Adaptation

The land use type with the highest income is adopted.

Appendix A.2.4. Objectives

In each cell, the objective is to select the land use type that maximizes profitability by using available natural resources and favorable weather and socio-economic patterns. If this is impossible, the land use and livelihood type that can easily be practiced based on existing infrastructure is selected.

Appendix A.2.5. Prediction

There is no foresight of rainfall or the trends in other socio-economic variables. In the cell, if livestock grazing is hampered by low water availability, low income and high human population, then it is likely that the land use will shift to a more profitable land use. 
Appendix A.2.6. Sensing

Before a different land use type is selected, the potential income of all land uses can be sensed and are used to inform land use change decisions.

Appendix A.2.7. Interaction

None.

Appendix A.2.8. Stochasticity

The state variables for each cell are randomly assigned when the model starts.

Appendix A.2.9. Observation

Observed variables per annual time steps are: land use types, annual income, average livestock (tropical livestock units) and wildlife density in each cell.

Appendix A.3. Details

Appendix A.3.1. Initialization

When the model begins, livestock grazing is the main land use type. The household density, distance to road, grass biomass, livestock and wildlife density have a normal distribution centered around the mean and standard deviation of each variable in Amboseli and Mara ecosystems (Table A1). The probability of irrigation is randomly allocated to the cells and range between zero and one. Income for each land use type is set to zero. For the land tenure scenarios:

- In the communal scenario, land tenure it is randomly allocated a 50\% chance of being communal, $25 \%$ of being government and $25 \%$ of being private.

- In the government scenario, land tenure is randomly given a chance of being $50 \%$ government, $25 \%$ communal and $25 \%$ private.

- In the private scenario, land tenure is randomly allocated a $50 \%$ chance of being private, $25 \%$ of being communal and $25 \%$ being government.

Table A1. Initialization state variable values.

\begin{tabular}{cccc}
\hline Variable & Amboseli & Mara & Source \\
\hline Mean household density & $13.18 / \mathrm{km}^{2}$ & $15.55 / \mathrm{km}^{2}$ & {$[74]$} \\
Mean distance to road & $9.4 \mathrm{~km}$ & $9.4 \mathrm{~km}$ & {$[73]$} \\
Mean grass biomass & $93,000 \mathrm{~kg} / \mathrm{km}^{2}$ & $2958 \mathrm{~kg} / \mathrm{km}^{2}$ & LPJGUESS DGVM \\
Mean TLU & $61.3 / \mathrm{km}^{2}$ & $71.06 / \mathrm{km}^{2}$ & {$[40]$} \\
Mean wildlife density & $33.33 / \mathrm{km}^{2}$ & $138.94 / \mathrm{km}^{2}$ & {$[39]$} \\
\hline
\end{tabular}

Appendix A.3.2. Submodels

Animal Grazing

The amount of grass grazed is a function of available grass biomass and the annual amount of dry matter $(\mathrm{kg})$ grazed by one TLU of livestock per year. The model assumes wildlife grazing habits are similar to those of livestock hence their annual grass offtake amounts are similar. One TLU feeds on $2500 \mathrm{~kg} / \mathrm{km}^{2}$ of dry matter per year [72] thus the formulas used for calculating livestock and wildlife density that can graze on a given cell in the three land use type are as follows: Note: agricultural and urban land use types have no livestock or wildlife grazing. 
i. Livestock grazing land use where all the land is exclusively used for livestock grazing

$$
T L U=\left(\frac{\text { Grass biomass }}{2500}\right)
$$

ii. Irrigated agro-pastoralism where half of the land is grazed by livestock and the other half is used for agriculture.

$$
T L U=\left(\frac{\text { Grass biomass } \times \frac{1}{2}}{2500}\right)
$$

iii. Livestock grazing with conservation activities where one third of the land is used for livestock grazing and two-thirds of the land is rented out for wildlife conservation.

$$
\begin{gathered}
T L U=\left(\frac{\text { Grass biomass } \times \frac{1}{3}}{2500}\right) \\
\text { Wildlife density }=\left(\frac{\text { Grass biomass } \times \frac{2}{3}}{2500}\right)
\end{gathered}
$$

Calculation of Income for Each Land use Type in Each Grazing Land

Income earned in each land use type differs. It depends on the interactions between social and the biophysical components of the system. Though each land tenure scenario has varying proportions of each land use type, livestock grazing is largely practiced in communal and government land while irrigated agropastoralism, agriculture and built-up areas are largely found on private land. The probability of irrigation is calculated as a ratio between irrigated area $[75,110]$ and the total area studied resulting in a probability of 0.013 and 0.1389 for Amboseli and Mara respectively.

In suitable areas, potential income for each land use type in each grazing land is calculated as follows:

i. Income from livestock grazing =

$$
\left(\frac{\text { Grass biomass }}{2500}\right) \times\left(\frac{\text { Cost }(\$) \text { of one TLU }}{\text { households }}\right)
$$

ii. Income from irrigated agropastoralism $=$

$$
\left(\left(\frac{\text { Mean household density }}{\text { households }}\right)+\left(\frac{\text { Grass biomass } \times \frac{1}{2}}{2500}\right) \times\left(\frac{\text { Cost }(\$) \text { of one TLU }}{\text { households }}\right)\right)
$$

iii. Income from irrigated agriculture $=$

$$
\text { (Agriculture income from literature } \times \frac{\text { Mean household density }}{\text { households }} \text { ) }
$$

iv. Income from livestock grazing and conservation =

$$
\text { (Amount of conservation subsidy } \left.+\left(\frac{\text { Grass biomass } \times \frac{1}{3}}{2500}\right) \times\left(\frac{\text { Cost }(\$) \text { of one TLU }}{\text { households }}\right)\right)
$$

v. The only built-up areas that earn pastoralists income are those $<2 \mathrm{~km}$ from all-weather roads with the income earned based on the mean income earned from urban areas in the study sites. 


\section{Appendix B. Comparison between Amboseli and Mara}

In Amboseli, although land use types are a result of long term changes in physical and cultural interactions, current trends of increasing sedentarization, agricultural expansion and development of conservation-based initiatives are more recent [38]. These land use trends are a result of infrastructure access, economic opportunities, land tenure changes and settlement patterns [40]. Access to physical infrastructure such as roads, schools, markets and health centers vary considerable across Amboseli and depend on the location of pastoral settlements [1]. Agriculture expanded on swamps and the slopes of Mt. Kilimanjaro which are dry season animal grazing zones [38,111].

In Mara, subdivided group ranches that receive adequate rainfall that can support agriculture have been converted to agriculture [40,92] leaving only $25-35 \%$ livestock available to maintain a nomadic livelihood [45]. When pastoralists in Mara are selecting land use types, they consider trade-offs between increasing the size of livestock or maintaining income from wildlife conservation activities and between expanding land for small scale farming or leasing land for mechanized farming [92]. In areas close to the Maasai Mara National Reserve, residents are involved in wildlife related and tourism activities. The national reserve accounts for $25 \%$ of the total national wildlife population in Kenya [14]. This makes wildlife conservation initiatives an integral component of the land use systems in Mara and contribution from wildlife conservation to most households is higher than livestock and agriculture income [40,45]. However, livestock still supports many livelihoods as integrating pastoralism with conservation has been challenging [92].

Wildlife declines in the rangelands have been attributed to agriculture expansion that results to habitat loss and fragmented landscapes of wildlife dispersal areas [14]. From the model, general wildlife trends show lower wildlife density in private land tenure compared to communal and government land and higher wildlife density in wet years relative to dry years. In Amboseli, the consequence of agricultural expansion in swamps in Amboseli has been fragmentation of wildlife dispersal zones, decline in dry season pasture, loss of wildlife habitat and intense human-wildlife conflicts $[38,109]$. The Mara rangelands have shown huge resilience in supporting large biomass of resident and migratory herbivores for years [92]. However, conversion of large tracts of rangelands on the Loita plains (north of the national reserve) to large scale commercial farms has led to habitat loss for wildlife, and consequently their decline [27,44,92].

\section{References}

1. Galvin, K.A.; Reid, R.S.; Behnke, R.H., Jr.; Hobbs, N.T. Fragmentation in Semi-Arid and Arid Landscapes: Consequences for Human and Natural Systems; Springer: Dordrecht, The Netherlands, 2008.

2. Milne, E.; Williams, S.E. Grazing Lands, Livestock and Climate Resilient Mitigation in Sub-Saharan Africa: State of the Science. Report for USAID Project Contract No. AIDOAAL1000001. Available online: http:/ / www.vivo.colostate.edu/lccrsp/reports/GrazingLandsLivestockClimateMitigation_Paper1_ Final6Aug2015editedv4a.pdf (accessed on 22 January 2018).

3. Reid, R.S.; Fernández-Giménez, M.E.; Galvin, K.A. Dynamics and Resilience of Rangelands and Pastoral Peoples Around the Globe. Annu. Rev. Environ. Resour. 2014, 39, 217-242. [CrossRef]

4. Scholes, R.J.; Archer, S.R. Tree-Grass Interactions in Savannas. Annu. Rev. Ecol. Syst. 1997, 28, 517-544. [CrossRef]

5. Plisnier, P.D.; Serneels, S.; Lambin, E.F. Impact of ENSO on East African Ecosystems: A Multivariate Analysis Based on Climate and Remote Sensing Data. Glob. Ecol. Biogeogr. 2000, 9, 481-497. [CrossRef]

6. Marchant, R.; Lane, P. Past perspectives for the future: Foundations for sustainable development in East Africa. J. Archaeol. Sci. 2014, 51, 12-21. [CrossRef]

7. Willcock, S.; Phillips, O.L.; Platts, P.J.; Balmford, A.; Burgess, N.D.; Lovett, J.C.; Ahrends, A.; Bayliss, J.; Doggart, N.; Doody, K.; et al. Quantifying and understanding carbon storage and sequestration within the Eastern Arc Mountains of Tanzania, a tropical biodiversity hotspot. Carbon Balance Manag. 2014, 9, 2. [CrossRef] [PubMed] 
8. Willcock, S.; Phillips, O.L.; Platts, P.J.; Swetnam, R.D.; Balmford, A.; Burgess, N.D.; Ahrends, A.; Bayliss, J.; Doggart, N.; Doody, K.; et al. Land cover change and carbon emissions over 100 years in an African biodiversity hotspot. Glob. Chang. Biol. 2016, 22, 2787-2800. [CrossRef] [PubMed]

9. Ellis, J.; Galvin, K.A. Climate Patterns and Land-Use Practices in the Dry Zones of Africa. Bioscience 1994, 44, 340-349. [CrossRef]

10. Western, D.; Nightingale, D.L.M. Environmental Change and the Vulnerability of Pastoralists to Drought: A Case Study of the Maasai in Amboseli, Kenya; Cambridge University Press: New York, NY, USA, 2003.

11. Dong, S.; Kassam, K.-A.S.; Tourrand, J.F.; Boone, R.B. Building Resilience of Human-Natural Systems of Pastoralism in the Developing World; Springer: Basel, Switzerland, 2016; p. 295.

12. Ogutu, J.O.; Piepho, H.P.; Dublin, H.T.; Bhola, N.; Reid, R.S. El Niño-Southern Oscillation, rainfall, temperature and Normalized Difference Vegetation Index fluctuations in the Mara-Serengeti ecosystem. Afr. J. Ecol. 2008, 46, 132-143. [CrossRef]

13. Galvin, K.A.; Thornton, P.K.; de Pinho, J.R.; Sunderland, J.; Boone, R.B. Integrated Modeling and Its Potential for Resolving Conflicts between Conservation and People in the Rangelands of East Africa. Hum. Ecol. 2006, 34, 155-183. [CrossRef]

14. Western, D.; Russell, S.; Cuthill, I. The status of wildlife in protected areas compared to non-protected areas of Kenya. PLoS ONE 2009, 4, e6140. [CrossRef] [PubMed]

15. Kiffner, C.; Wenner, C.; LaViolet, A.; Yeh, K.; Kioko, J. From savannah to farmland: Effects of land-use on mammal communities in the Tarangire-Manyara ecosystem, Tanzania. Afr. J. Ecol. 2015, 53, 156-166. [CrossRef]

16. Western, D. Amboseli National Park: Enlisting landowners to conserve migratory wildlife. AMBIO 1982, 11, 302-308.

17. Bedelian, C.; Ogutu, J.O. Trade-offs for climate-resilient pastoral livelihoods in wildlife conservancies in the Mara ecosystem, Kenya. Pastoralism 2017, 7, 10. [CrossRef]

18. Opiyo, F.; Wasonga, O.; Nyangito, M.; Schilling, J.; Munang, R. Drought Adaptation and Coping Strategies Among the Turkana Pastoralists of Northern Kenya. Int. J. Disaster Risk Sci. 2015, 6, 295-309. [CrossRef]

19. Boone, R.B.; Burnsilver, S.B.; Thornton, P.K.; Worden, J.S.; Galvin, K.A. Quantifying Declines in Livestock Due to Land Subdivision. Rangel. Ecol. Manag. 2005, 58, 523-532. [CrossRef]

20. Campbell, D.J. Response to Drought Among Farmers and Herders in Southern Kajiado District, Kenya. Hum. Ecol. 1984, 12, 35-64. [CrossRef]

21. Riginos, C.; Porensky, L.M.; Veblen, K.E.; Odadi, W.O.; Sensenig, R.L.; Kimuyu, D.; Keesing, F.; Wilkerson, M.L.; Young, T.P. Lessons on the relationship between livestock husbandry and biodiversity from the Kenya Long-term Exclosure Experiment (KLEE). Pastor. Res. Policy Pract. 2012, 2. [CrossRef]

22. Campbell, D.J.; Gichohi, H.; Mwangi, A.; Chege, L. Land use conflict in Kajiado district, Kenya. Land Use Policy 2000, 17, 337-348. [CrossRef]

23. Hobbs, N.T.; Galvin, K.A.; Stokes, C.J.; Lackett, J.M.; Ash, A.J.; Boone, R.B.; Reid, R.S.; Thornton, P.K. Fragmentation of rangelands: Implications for humans, animals, and landscapes. Glob. Environ. Chang. 2008, 18, 776-785. [CrossRef]

24. Western, D.; Groom, R.; Worden, J. The impact of subdivision and sedentarization of pastoral lands on wildlife in an African savanna ecosystem. Biol. Conserv. 2009, 142, 2538-2546. [CrossRef]

25. Galaty, J.G. Reasserting the commons: Pastoral contestations of private and state lands in East Africa. Int. J. Commons 2016, 10, 709. [CrossRef]

26. Greiner, C.; Mwaka, I. Agricultural change at the margins: Adaptation and intensification in a Kenyan dryland. J. East. Afr. Stud. 2016, 10, 130-149. [CrossRef]

27. Serneels, S.; Lambin, F.E. Proximate causes of land-use change in Narok District, Kenya: A spatial statistical model. Agric. Ecosyst. Environ. 2001, 85, 65-84. [CrossRef]

28. Greiner, C.; Alvarez, M.; Becker, M. From Cattle to Corn: Attributes of Emerging Farming Systems of Former Pastoral Nomads in East Pokot, Kenya. Soc. Nat. Resour. 2013, 26, 1478-1490. [CrossRef]

29. Bhola, N.; Ogutu, J.O.; Said, M.Y.; Piepho, H.P.; Olff, H. The distribution of large herbivore hotspots in relation to environmental and anthropogenic correlates in the Mara region of Kenya. J. Anim. Ecol. 2012, 81, 1268-1287. [CrossRef] [PubMed] 
30. Franz, T.E.; Caylor, K.K.; Nordbotten, J.M.; Rodríguez-Iturbe, I.; Celia, M.A. An ecohydrological approach to predicting regional woody species distribution patterns in dryland ecosystems. Adv. Water Resour. 2010, 33, 215-230. [CrossRef]

31. Mwangi, E.; Ostrom, E. A Century of Institutions and Ecology in East Africa's Rangelands: Linking Institutional Robustness with the Ecological Resilience of Kenya's Maasailand. In Institutions and Sustainability: Political Economy of Agriculture and the Environment-Essays in Honour of Konrad Hagedorn; Beckmann, V., Padmanabhan, M., Eds.; Springer: Dordrecht, The Netherlands, 2009; pp. 195-222.

32. Orach, K.; Schlüter, M. Uncovering the political dimension of social-ecological systems: Contributions from policy process frameworks. Glob. Environ. Chang. 2016, 40, 13-25. [CrossRef]

33. Miyasaka, T.; Le, Q.B.; Okuro, T.; Zhao, X.; Takeuchi, K. Agent-based modeling of complex social-ecological feedback loops to assess multi-dimensional trade-offs in dryland ecosystem services. Landsc. Ecol. 2017, 32, 707-727. [CrossRef]

34. Boone, R.B.; Galvin, K.; BurnSilver, S.B.; Thornton, P.; Ojima, D.; Jawson, J. Using coupled simulation models to link pastoral decision making and ecosystem services. Ecol. Soc. 2011, 16. [CrossRef]

35. Ntiati, P. Land Use Change Impacts and Dynamics (LUCID) Project Working Paper 7; International Livestock Research Institute: Nairobi, Kenya, 2002.

36. Kimani, K.; Pickard, J. Recent trends and implications of group ranch sub-division and fragmentation in Kajiado District, Kenya. Geogr. J. 1998, 164, 202-213. [CrossRef]

37. Altmann, J.; Alberts, S.C.; Altmann, S.A.; Roy, S.B. Dramatic change in local climate patterns in the Amboseli basin, Kenya. Afr. J. Ecol. 2002, 40, 248-251. [CrossRef]

38. Worden, J.; Reid, R.S.; Gichohi, H. Land-Use Impacts on Large Wildlife and Livestock in the Swamps of the Greater Amboseli Ecosystem; Kajiado District, Kenya (LUCID) Project Working Paper 27; International Livestock Research Institute: Nairobi, Kenya, 2003.

39. Okello, M.M.; Kenana, L.; Maliti, H.; Kiringe, J.W.; Kanga, E.; Warinwa, F.; Bakari, S.; Ndambuki, S.; Massawe, E.; Sitati, N.; et al. Population density of elephants and other key large herbivores in the Amboseli ecosystem of Kenya in relation to droughts. J. Arid Environ. 2016, 135, 64-74. [CrossRef]

40. Homewood, K.; Kristjanson, P.; Trench, P. Staying Maasai? Livelihoods, Conservation and Development in East African Rangelands; Springer Science \& Business Media: Dordrecht, The Netherlands, 2009; Volume 5.

41. Rucina, S.M.; Muiruri, V.M.; Downton, L.; Marchant, R. Late-Holocene savanna dynamics in the Amboseli Basin, Kenya. Holocene 2010, 20, 667-677. [CrossRef]

42. Reid, R.S.; Nkedianye, D.; Said, M.Y.; Kaelo, D.; Neselle, M.; Makui, O.; Onetu, L.; Kiruswa, S.; Kamuaro, N.O.; Kristjanson, P.; et al. Evolution of models to support community and policy action with science: Balancing pastoral livelihoods and wildlife conservation in savannas of East Africa. Proc. Natl. Acad. Sci. USA 2016, 113, 4579-4584. [CrossRef] [PubMed]

43. Serneels, S.; Said, M.Y.; Lambin, E.F. Land cover changes around a major east African wildlife reserve: The Mara Ecosystem (Kenya). Int. J. Remote Sens. 2001, 22, 3397-3420. [CrossRef]

44. Homewood, K.; Lambin, E.F.; Coast, E.; Kariuki, A.; Kikula, I.; Kivelia, J.; Said, M.; Serneels, S.; Thompson, M. Long-term changes in Serengeti-Mara wildebeest and land cover: Pastoralism, population, or policies? Proc. Natl. Acad. Sci. USA 2001, 98, 12544-12549. [CrossRef] [PubMed]

45. Waithaka, J. Maasai Mara-An ecosystem under siege: An African case study on the societal dimension of rangeland conservation. Afr. J. Range Forage Sci. 2004, 21, 79-88. [CrossRef]

46. Robertshaw, P. Early Pastoralists of South-Western Kenya; British Institute in Eastern Africa: Nairobi, Kenya, 1990.

47. Macal, C.M.; North, M.J. Tutorial on agent-based modelling and simulation. J. Simul. 2010, 4, 151-162. [CrossRef]

48. Rounsevell, M.D.; Robinson, D.T.; Murray-Rust, D. From actors to agents in socio-ecological systems models. Philos. Trans. R. Soc. Lond. B Boil. Sci. 2012, 367, 259-269. [CrossRef] [PubMed]

49. Moritz, M.; Buffington, A.; Yoak, A.J.; Hamilton, I.M.; Garabed, R. No Magic Number: An Examination of the Herd-Size Threshold in Pastoral Systems Using Agent-Based Modeling. Hum. Ecol. 2017, 45, 525-532. [CrossRef]

50. Bert, F.E.; Rovere, S.L.; Macal, C.M.; North, M.J.; Podestá, G.P. Lessons from a comprehensive validation of an agent based-model: The experience of the Pampas Model of Argentinean agricultural systems. Ecol. Model. 2014, 273, 284-298. [CrossRef] 
51. Matthews, R.B.; Bakam, I. A combined agent-based and biophysical modelling approach to address GHG mitigation policy issues. In Proceedings of the MODSIM International Congress on Modelling and Simulation, Christchurch, New Zealand, 10-13 December 2007.

52. Mialhe, F.; Becu, N.; Gunnell, Y. An agent-based model for analyzing land use dynamics in response to farmer behaviour and environmental change in the Pampanga delta (Philippines). Agric. Ecosyst. Environ. 2012, 161, 55-69. [CrossRef]

53. Filatova, T.; Verburg, P.H.; Parker, D.C.; Stannard, C.A. Spatial agent-based models for socio-ecological systems: Challenges and prospects. Environ. Model. Softw. 2013, 45, 1-7. [CrossRef]

54. Iwamura, T.; Lambin, E.F.; Silvius, K.M.; Luzar, J.B.; Fragoso, J.M.V. Agent-based modeling of hunting and subsistence agriculture on indigenous lands: Understanding interactions between social and ecological systems. Environ. Model. Softw. 2014, 58, 109-127. [CrossRef]

55. Matthews, R.B.; Gilbert, N.G.; Roach, A.; Polhill, J.G.; Gotts, N.M. Agent-based land-use models: A review of applications. Landsc. Ecol. 2007, 22, 1447-1459. [CrossRef]

56. Smith, B.; Prentice, I.C.; Sykes, M.T. Representation of vegetation dynamics in the modelling of terrestrial ecosystems: Comparing two contrasting approaches within European climate space. Glob. Ecol. Biogeogr. 2001, 10, 621-637. [CrossRef]

57. Smith, B.; Wårlind, D.; Arneth, A.; Hickler, T.; Leadley, P.; Siltberg, J.; Zaehle, S. Implications of incorporating $\mathrm{N}$ cycling and $\mathrm{N}$ limitations on primary production in an individual-based dynamic vegetation model. Biogeosciences 2014, 11, 2027-2054. [CrossRef]

58. Lindeskog, M.; Arneth, A.; Bondeau, A.; Waha, K.; Seaquist, J.; Olin, S.; Smith, B. Implications of accounting for land use in simulations of ecosystem services and carbon cycling in Africa. Earth Syst. Dyn. Discuss. 2013, 4, 235-278. [CrossRef]

59. Pachzelt, A.; Rammig, A.; Higgins, S.; Hickler, T. Coupling a physiological grazer population model with a generalized model for vegetation dynamics. Ecol. Model. 2013, 263, 92-102. [CrossRef]

60. Ahlström, A.; Xia, J.; Arneth, A.; Luo, Y.; Smith, B. Importance of vegetation dynamics for future terrestrial carbon cycling. Environ. Res. Lett. 2015, 10. [CrossRef]

61. Jönsson, A.M.; Lagergren, F.; Smith, B. Forest management facing climate change-An ecosystem model analysis of adaptation strategies. Mitig. Adapt. Strateg. Glob. Chang. 2013, 20, 201-220. [CrossRef]

62. Wu, Z.; Ahlström, A.; Smith, B.; Ardö, J.; Eklundh, L.; Fensholt, R.; Lehsten, V. Climate data induced uncertainty in model-based estimations of terrestrial primary productivity. Environ. Res. Lett. 2017, 12. [CrossRef]

63. Krause, A.; Pugh, T.A.M.; Bayer, A.D.; Doelman, J.C.; Humpenöder, F.; Anthoni, P.; Olin, S.; Bodirsky, B.L.; Popp, A.; Stehfest, E.; et al. Global consequences of afforestation and bioenergy cultivation on ecosystem service indicators. Biogeosciences 2017, 14, 4829-4850. [CrossRef]

64. Hely, C.; Bremond, L.; Alleaume, S.; Smith, B.; Sykes, M.T.; Guiot, J. Sensitivity of African biomes to changes in the precipitation regime. Glob. Ecol. Biogeogr. 2006, 15, 258-270. [CrossRef]

65. Fer, I.; Tietjen, B.; Jeltsch, F. High-resolution modelling closes the gap between data and model simulations for Mid-Holocene and present-day biomes of East Africa. Palaeogeogr. Palaeoclimatol. Palaeoecol. 2016, 444, 144-151. [CrossRef]

66. Ostrom, E. A General Framework for Analyzing Sustainability of Social-Ecological Systems. Science 2009, 325, 419-422. [CrossRef] [PubMed]

67. Wilensky, U. Center for Connected Learning and Computer-Based Modeling, NetLogo (and NetLogo User Manual). Available online: http:/ / ccl.northwestern.edu/netlogo (accessed on 11 April 2018).

68. Grimm, V.; Berger, U.; DeAngelis, D.L.; Polhill, J.G.; Giske, J.; Railsback, S.F. The ODD protocol: A review and first update. Ecol. Model. 2010, 221, 2760-2768. [CrossRef]

69. Grimm, V.; Berger, U.; Bastiansen, F.; Eliassen, S.; Ginot, V.; Giske, J.; Goss-Custard, J.; Grand, T.; Heinz, S.K.; Huse, G.; et al. A standard protocol for describing individual-based and agent-based models. Ecol. Model. 2006, 198, 115-126. [CrossRef]

70. Polhill, G.J.; Parker, D.; Brown, D.G.; Grimm, V. Using the ODD Protocol for Describing Three Agent-Based Social Simulation Models of Land-Use Change. Available online: http://jasss.soc.surrey.ac.uk/11/2/3.html (accessed on 11 April 2018). 
71. BurnSilver, S.B.; Worden, J.; Boone, R.B. Processes of Fragmentation in the Amboseli Ecosystem, Southern Kajiado District, Kenya. In Fragmentation in Semi-Arid and Arid Landscapes; Springer: Dordrecht, The Netherlands, 2008; pp. 225-253.

72. De Leeuw, P.N.; Tothill, J.C. The Concept of Rangeland Carrying Capacity in Sub-Saharan Africa: Myth or Reality; Overseas Development Institute, Pastoral Development Network London: London, UK, 1990.

73. Nkedianye, D.; Radeny, M.; Kristjanson, P.; Herrero, M. Assessing Returns to Land and Changing Livelihood Strategies in Kitengela. In Staying Maasai? Springer: New York, NY, USA, 2009; Volume 5, pp. 115-149.

74. Kenya National Bureau of Statistics, K. Kenya Demographic and Health Survey 2008-2009; Kenya National Bureau of Statistics: Nairobi, Kenya, 2010.

75. Amboseli Ecosystem Stakeholders. Amboseli Ecosystem Management Plan (2008-2018). Available online: http:/ / www.amboseliecosystemtrust.org/uploads/3/7/4/8/3748244/amboseli_ecosystem_final_ plan-jan_2009.pdf (accessed on 11 April 2018).

76. Osano, P.M.; Leal Filho, W.; Said, M.Y.; de Leeuw, J.; Moiko, S.S.; Ole Kaelo, D.; Schomers, S.; Birner, R.; Ogutu, J.O. Pastoralism and ecosystem-based adaptation in Kenyan Masailand. Int. J. Clim. Chang. Strateg. Manag. 2013, 5, 198-214. [CrossRef]

77. Kibet, S.; Nyangito, M.; MacOpiyo, L.; Kenfack, D. Tracing innovation pathways in the management of natural and social capital on Laikipia Maasai Group Ranches, Kenya. Pastoralism 2016, 6, 16. [CrossRef]

78. McCabe, J.; Smith, N.; Leslie, P.; Telligman, A. Livelihood diversification through migration among a pastoral people: Contrasting case studies of Maasai in northern Tanzania. Hum. Org. 2014, 73, 389-400. [CrossRef]

79. Grimm, V.; Revilla, E.; Berger, U.; Jeltsch, F.; Mooij, W.M.; Railsback, S.F.; Thulke, H.-H.; Weiner, J.; Wiegand, T.; DeAngelis, D.L. Pattern-Oriented Modeling of Agent-Based Complex Systems: Lessons from Ecology. Science 2005, 310, 987-991. [CrossRef] [PubMed]

80. Climate Research Unit (CRU) University of East Anglia. CRU Time Series (CRUTS) High Resolution Gridded Datasets. Available online: https://crudata.uea.ac.uk/cru/data/hrg/ (accessed on 11 April 2018).

81. Bodin, P.; Olin, S.; Pugh, T.A.M.; Arneth, A. Accounting for interannual variability in agricultural intensification: The potential of crop selection in Sub-Saharan Africa. Agric. Syst. 2016, 148, 159-168. [CrossRef]

82. Bulte, E.H.; Boone, R.B.; Stringer, R.; Thornton, P.K. Elephants or onions? Paying for nature in Amboseli, Kenya. Environ. Dev. Econ. 2008, 13, 395-414. [CrossRef]

83. Thornton, P.K.; BurnSilver, S.B.; Boone, R.B.; Galvin, K.A. Modelling the impacts of group ranch subdivision on agro-pastoral households in Kajiado, Kenya. Agric. Syst. 2006, 87, 331-356. [CrossRef]

84. Rasmussen, L.V.; Rasmussen, K.; Reenberg, A.; Proud, S. A system dynamics approach to land use changes in agro-pastoral systems on the desert margins of Sahel. Agric. Syst. 2012, 107, 56-64. [CrossRef]

85. Sundstrom, S.; Tynon, J.F.; Western, D. Rangeland Privatization and the Maasai Experience: Social Capital and the Implications for Traditional Resource Management in Southern Kenya. Soc. Nat. Resour. 2012, 25, 483-498. [CrossRef]

86. Zinsstag, J.; Bonfoh, B.; Zinsstag, G.; Crump, L.; Alfaroukh, I.O.; Abakar, M.F.; Kasymbekov, J.; Baljinnyam, Z.; Liechti, K.; Seid, M.A.; et al. A vision for the future of pastoralism. Rev. Sci. Tech. 2016, 35, 693-699. [CrossRef] [PubMed]

87. Kirkbride, M.; Grahn, R. Survival of the fittest: Pastoralism and climate change in East Africa. Oxfam Policy Pract. Agric. Food Land 2008, 8, 174-220.

88. Galvin, K.A. Transitions: Pastoralists Living with Change. Annu. Rev. Anthropol. 2009, 38, $185-198$. [CrossRef]

89. Martin, R.; Müller, B.; Linstädter, A.; Frank, K. How much climate change can pastoral livelihoods tolerate? Modelling rangeland use and evaluating risk. Glob. Environ. Chang. 2014, 24, 183-192. [CrossRef]

90. Pricope, N.G.; Husak, G.; Lopez-Carr, D.; Funk, C.; Michaelsen, J. The climate-population nexus in the East African Horn: Emerging degradation trends in rangeland and pastoral livelihood zones. Glob. Environ. Chang. 2013, 23, 1525-1541. [CrossRef]

91. Martin, R.; Linstädter, A.; Frank, K.; Müller, B. Livelihood security in face of drought-Assessing the vulnerability of pastoral households. Environ. Model. Softw. 2016, 75, 414-423. [CrossRef]

92. Lamprey, R.H.; Reid, R.S. Expansion of human settlement in Kenya's Maasai Mara: What future for pastoralism and wildlife? J. Biogeogr. 2004, 31, 997-1032. [CrossRef] 
93. Ogutu, J.O.; Piepho, H.P.; Dublin, H.T.; Bhola, N.; Reid, R.S. Dynamics of Mara-Serengeti ungulates in relation to land use changes. J. Zool. 2009, 278, 1-14. [CrossRef]

94. Basupi, L.V.; Quinn, C.H.; Dougill, A.J. Historical perspectives on pastoralism and land tenure transformation in Ngamiland, Botswana: What are the policy and institutional lessons? Pastoralism 2017, 7. [CrossRef]

95. Dong, S.; Wen, L.; Liu, S.; Zhang, X.; Lassoie, J.P.; Yi, S.; Li, X.; Li, J.; Li, Y. Vulnerability of Worldwide Pastoralism to Global Changes and Interdisciplinary Strategies for Sustainable Pastoralism. Ecol. Soc. 2011, 16, 85-99. [CrossRef]

96. Seno, S.K.; Shaw, W.W. Land Tenure Policies, Maasai Traditions, and Wildlife Conservation in Kenya. Soc. Nat. Resour. 2002, 15, 79-88. [CrossRef]

97. Gadd, M.E. Conservation outside of parks: Attitudes of local people in Laikipia, Kenya. Environ. Conserv. 2005, 32, 50-63. [CrossRef]

98. Wishitemi, B.E.L.; Momanyi, S.O.; Ombati, B.G.; Okello, M.M. The link between poverty, environment and ecotourism development in areas adjacent to Maasai Mara and Amboseli protected areas, Kenya. Tour. Manag. Perspect. 2015, 16, 306-317. [CrossRef]

99. Ogutu, J.O.; Kuloba, B.; Piepho, H.P.; Kanga, E. Wildlife Population Dynamics in Human-Dominated Landscapes under Community-Based Conservation: The Example of Nakuru Wildlife Conservancy, Kenya. PLoS ONE 2017, 12, e0169730. [CrossRef] [PubMed]

100. Jandreau, C.; Berkes, F. Continuity and change within the social-ecological and political landscape of the Maasai Mara, Kenya. Pastoralism 2016, 6. [CrossRef]

101. Vuorio, V.; Muchiru, A.; Reid, R.S.; Ogutu, J.O. How pastoralism changes savanna vegetation: Impact of old pastoral settlements on plant diversity and abundance in south-western Kenya. Biodivers. Conserv. 2014, 23, 3219-3240. [CrossRef]

102. Boone, R.B.; Lesorogol, C.K. Modeling Coupled Human-Natural Systems of Pastoralism in East Africa. In Building Resilience of Human-Natural Systems of Pastoralism in the Developing World; Springer: Dordrecht, The Netherlands, 2016; pp. 251-280.

103. Thompson, M.; Homewood, K. Entrepreneurs, elites, and exclusion in Maasailand: Trends in wildlife conservation and pastoralist development. Hum. Ecol. 2002, 30, 107-138. [CrossRef]

104. Groom, R.J.; Western, D. Impact of Land Subdivision and Sedentarization on Wildlife in Kenya's Southern Rangelands. Rangel. Ecol. Manag. 2013, 66, 1-9. [CrossRef]

105. Lee, J.-S.; Filatova, T.; Ligmann-Zielinska, A.; Hassani-Mahmooei, B.; Stonedahl, F.; Lorscheid, I.; Voinov, A.; Polhill, G.; Sun, Z.; Parker, D.C. The Complexities of Agent-Based Modeling Output Analysis. J. Artif. Soc. Soc. Simul. 2015, 18. [CrossRef]

106. Ward, J.A.; Evans, A.J.; Malleson, N.S. Dynamic calibration of agent-based models using data assimilation. R. Soc. Open Sci. 2016, 3. [CrossRef] [PubMed]

107. Platts, P.J.; Omeny, P.A.; Marchant, R. AFRICLIM: High-resolution climate projections for ecological applications in Africa. Afr. J. Ecol. 2014, 53, 103-108. [CrossRef]

108. Anderson, D.M.; Bollig, M. Resilience and collapse: Histories, ecologies, conflicts and identities in the Baringo-Bogoria basin, Kenya. J. East. Afr. Stud. 2016, 10, 1-20. [CrossRef]

109. Okello, M.M.; Buthmann, E.; Mapinu, B.; Kahi, H.C. Community Opinions on Wildlife, Resource Use and Livelihood Competition in Kimana Group Ranch Near Amboseli, Kenya. Open Conserv. Biol. J. 2011, 5, 1-12. [CrossRef]

110. Water Resources and Energy Management International. Mara River Basin Monograph, Mara River Basin Transboundary Integrated Water Resources Management and Development Project; Final Technical Report; Water Resources and Energy Management International Inc.: Atlanta, GA, USA, 2008.

111. Okello, M.M.; D'Amour, D.E. Agricultural expansion within Kimana electric fences and implications for natural resource conservation around Amboseli National Park, Kenya. J. Arid Environ. 2008, 72, 2179-2192. [CrossRef]

(C) 2018 by the authors. Licensee MDPI, Basel, Switzerland. This article is an open access article distributed under the terms and conditions of the Creative Commons Attribution (CC BY) license (http:/ / creativecommons.org/licenses/by/4.0/). 